\title{
Preparation and study of thickness dependent electrical characteristics of zinc sulfide thin films
}

\author{
A U UBALE* and D K KULKARNI \\ Department of Physics, Govt Vidarbha Institute of Science and Humanities, Amravati 444 604, India \\ ${ }^{\dagger}$ Department of Physics, Institute of Science, Nagpur 440 001, India
}

MS received 26 July 2004; revised 2 November 2004

\begin{abstract}
Zinc sulfide thin films have been deposited onto glass substrates by chemical bath deposition. The various deposition parameters such as volume of sulfide ion source, $\mathrm{pH}$ of bath, deposition time, temperature etc are optimized. Thin films of $\mathrm{ZnS}$ with different thicknesses of 76-332 $\mathrm{nm}$ were prepared by changing the deposition time from 6-20 $\mathrm{h}$ at $30^{\circ} \mathrm{C}$ temperature. The effect of film thickness on structural and electrical properties was studied. The electrical resistivity was decreased from $1.83 \times 10^{5} \Omega$-cm to $0.363 \times 10^{5} \Omega$-cm as film thickness decreased from $332 \mathrm{~nm}$ to $76 \mathrm{~nm}$. The structural and activation energy studies support this decrease in the resistivity due to improvement in crystallinity of the films which would increase the charge carrier mobility and decrease in defect levels with increase in the thickness.
\end{abstract}

Keywords. Zinc sulfide; electrical properties; nanostructures.

\section{Introduction}

Recent investigations have evoked considerable interest in $\mathrm{ZnS}$ thin films due to their vast potential for use in thin film devices such as photoluminescent and electroluminescent devices and more recently as $n$-type windowlayer heterojunction solar cells (Ortega Borges et al 1992). Zinc sulfide has found wide use as a thin film coating in the optical and microelectronic industries. It has high refractive index $(2.25$ at $632 \mathrm{~nm})$, high effective dielectric constant ( 9 at $1 \mathrm{MHz}$ ) and wide wavelength passband $(0.4-13 \mu \mathrm{m})$ (Orient Tom 1994). It is commonly used as filter, reflector and planar waveguide. It is also the most commonly used host material in thin film electroluminescence devices (Mach and Muller 1982). Chemical deposition of $\mathrm{ZnS}$ films has been carried out by a number of workers. Biswas and his co-workers reported a chemical method for the deposition of $\mathrm{ZnS}$ thin films at $30^{\circ} \mathrm{C}$ on glass substrate (Biswas et al 1986). In this paper, we report the preparation of $\mathrm{ZnS}$ films in alkaline medium.

\section{Experimental}

A very attractive method for producing $\mathrm{ZnS}$ thin films due to possibility of large area deposition of some sulphides and selenides is the so called chemical bath deposition (CBD) method (Kitaev et al 1965; Kitaev and Sokolova 1970; Kaur et al 1980; Dona and Herrero 1992). But, there are only a few reports on $\mathrm{ZnS}$ by $\mathrm{CBD}$ where the

*Author for correspondence (ashokuu@yahoo.com) main objective is the study of $\mathrm{Zn}_{x} \mathrm{Cd}_{1-x} \mathrm{~S}$ thin films (Padam et al 1988; Lokhande 1991). Chemical deposition of $\mathrm{ZnS}$ thin films has been reported earlier using different zinc ion releasing sources such as zinc sulphate, zinc chloride etc. In the present case, $\mathrm{ZnS}$ films have been deposited chemically using thiourea as a sulfide ion source and zinc acetate as zinc ion source.

$\mathrm{ZnS}$ thin films are prepared by decomposition of thiourea in an alkaline solution containing a zinc salt and a suitable complexing agent. The deposition process is based on the slow release of $\mathrm{Zn}^{2+}$ and $\mathrm{S}^{2-}$ ions in solution which then condense on the substrate. The deposition of $\mathrm{ZnS}$ occurs when the ionic product of $\mathrm{Zn}^{2+}$ and $\mathrm{S}^{2-}$ exceeds the solubility product of $\mathrm{ZnS}$.

For preparation of $\mathrm{ZnS}$ films, $0 \cdot 2 \mathrm{M}$ zinc acetate solution was taken in a beaker and equal volume of $0.2 \mathrm{M}$ thiourea solution was added. Ammonia solution was added slowly to form the complex and $\mathrm{pH}$ was raised between 9 and 10. The solution was stirred for 5-6 s and then transferred to another beaker containing cleaned glass substrate. The mixture was kept at $30^{\circ} \mathrm{C}$ temperature. After about $18 \mathrm{~h}$ the slide covered with a white deposit was taken out, washed with distilled water and dried in a desiccator.

\section{Results and discussion}

\subsection{Reaction mechanism}

The formation of $\mathrm{ZnS}$ involves following steps. Zinc acetate dissociates as

$$
\mathrm{Zn}\left(\mathrm{CH}_{3} \mathrm{COO}\right)_{2} \longrightarrow \mathrm{Zn}^{2+}+2 \mathrm{CH}_{3} \mathrm{COO}^{-} \text {. }
$$


In the present case, ammonia hydrolyses in water to give $\mathrm{OH}^{-}$according to

$$
\mathrm{NH}_{3}+\mathrm{H}_{2} \mathrm{O} \rightleftarrows \mathrm{NH}_{4}^{+}+\mathrm{OH}^{-} \text {. }
$$

We can expect that the $\mathrm{Zn}^{2+}$ ions have to be in the form of $\mathrm{Zn}(\mathrm{OH})_{2}$ precipitate, however, it is not true due to the presence of $\mathrm{NH}_{3}$ which forms with $\mathrm{Zn}^{2+}$ and the complex, $\mathrm{Zn}\left(\mathrm{NH}_{3}\right)_{2}^{2+}$, which is soluble in this medium.

$$
\mathrm{Zn}^{2+}+4 \mathrm{NH}_{3} \rightleftarrows \mathrm{Zn}\left(\mathrm{NH}_{3}\right)_{4}^{2+} \text {. }
$$

In case of thiourea as the $\mathrm{S}^{2-}$ source, in an alkaline medium, the sulphide ions are released as follows

$$
\begin{aligned}
& \mathrm{SC}\left(\mathrm{NH}_{2}\right)_{2}+\mathrm{OH}^{-} \longrightarrow \mathrm{SH}^{-}+\mathrm{CH}_{2} \mathrm{~N}_{2}+\mathrm{H}_{2} \mathrm{O}, \\
& \mathrm{SH}^{-}+\mathrm{OH}^{-} \rightleftarrows \mathrm{S}^{2-}+\mathrm{H}_{2} \mathrm{O} .
\end{aligned}
$$

From (3) and (5), assuming a complex $\mathrm{Zn}^{2+}$ ion in the form of $\mathrm{Zn}\left(\mathrm{NH}_{3}\right)_{4}^{2+}$, the global reaction for the process is

$$
\begin{aligned}
& \mathrm{Zn}\left(\mathrm{NH}_{3}\right)_{4}^{2+}+\mathrm{SC}\left(\mathrm{NH}_{2}\right)_{2}+2 \mathrm{OH}^{-} \longrightarrow \mathrm{ZnS}+ \\
& 4 \mathrm{NH}_{3}+\mathrm{CH}_{2} \mathrm{~N}_{2}+2 \mathrm{H}_{2} \mathrm{O} .
\end{aligned}
$$

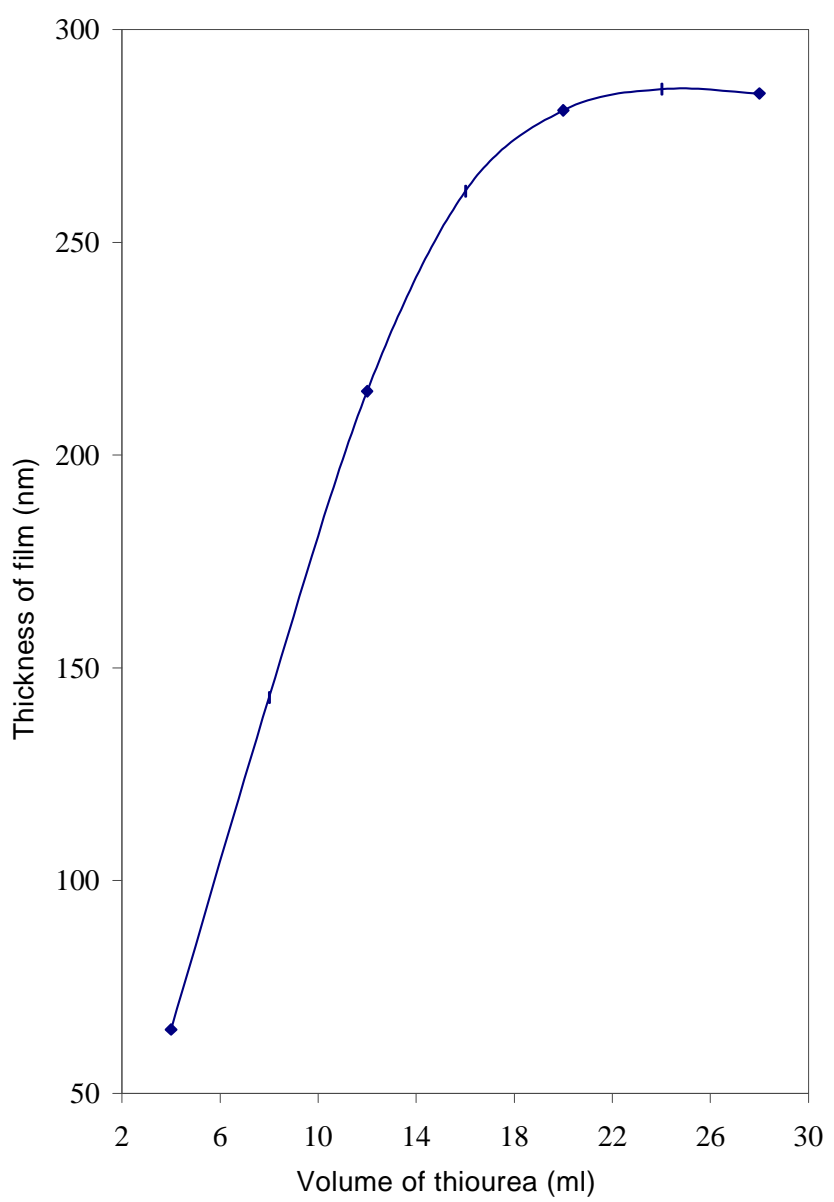

Figure 1. Optimization of volume of sulfide ion source (Deposition time, $16 \mathrm{~h}$; temperature of bath, $30^{\circ} \mathrm{C}$; $\mathrm{pH}$ of the bath, 9.0-10).

\subsection{Optimization of preparative parameters}

3.2a Volume of sulphide ion source: For optimization of volume of sulphide ion source, concentration of zinc acetate $(0.2 \mathrm{M}), \mathrm{pH}(\sim 9.5)$ of the bath, temperature $\left(30^{\circ} \mathrm{C}\right)$ and deposition time $(16 \mathrm{~h})$ are kept constant. The variation of $\mathrm{ZnS}$ film thickness with thiourea volume for $20 \mathrm{ml}$ zinc acetate with $\mathrm{NH}_{3}$, and $16 \mathrm{~h}$ deposition time is shown in figure 1 . When ionic product (IP) of $\mathrm{Zn}^{2+}$ and $S^{2-}$ exceeds the solubility product (SP) (i.e. $S>1$ ) of $\mathrm{ZnS}, \mathrm{ZnS}$ is formed. Ions form $\mathrm{ZnS}$ nuclei onto substrate and in solution which grow with time to give the film. Rate of deposition becomes zero when $S<1$ and film attains terminal thickness.

The rate of deposition is high in the initial process of growth due to high concentrations of $\mathrm{Zn}^{2+}$ and $\mathrm{S}^{2-}$. As more and more $\mathrm{ZnS}$ is formed, solution becomes deficient in ions giving lower rate of deposition. Rate of deposition becomes zero when $S \leq 1$, and film attains terminal thickness. After attaining terminal thickness further additional volume of thiourea does not increase thickness of film as appropriate volume of thiourea $(\sim 20 \mathrm{ml})$ is utilized.

3.2b Optimization of deposition time: Deposition time is optimized by taking a substrate out of bath at regular interval of $2 \mathrm{~h}$. Figure 2 shows the variation of film thickness with deposition time. Film thickness increases up to $20 \mathrm{~h}$ deposition time and then remains nearly constant. The average rate of deposition is $18.6 \mathrm{~nm} / \mathrm{h}$. The maximum thickness obtained by this method is about $332 \mathrm{~nm}$. The maximum rate of deposition is $28 \mathrm{~nm} / \mathrm{h}$ at 14 th $\mathrm{h}$.

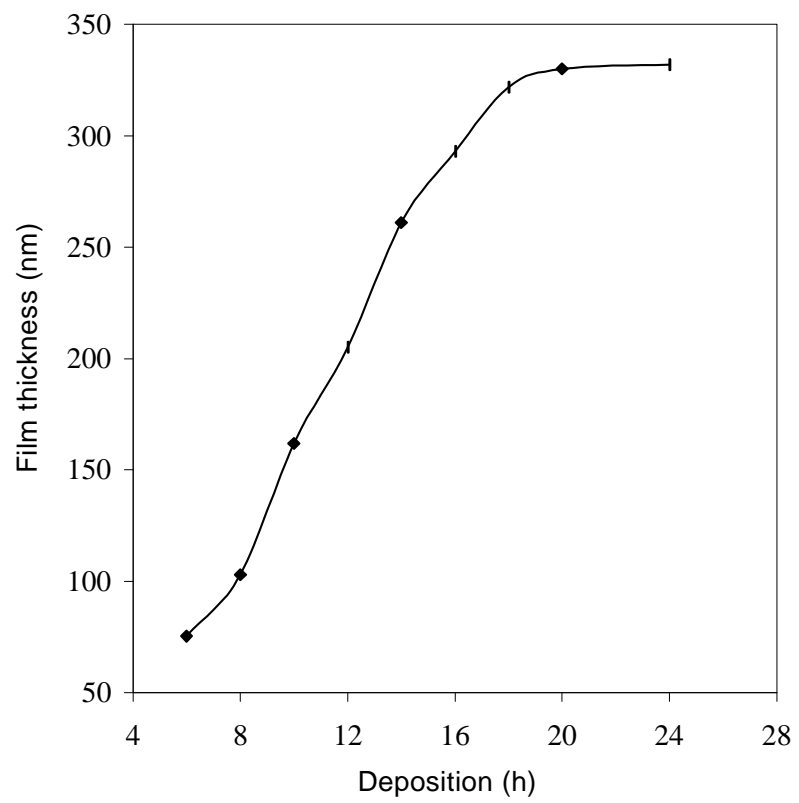

Figure 2. Variation of $\mathrm{ZnS}$ film thickness with deposition time (Bath composition: zinc acetate $(0 \cdot 2 \mathrm{M}) ; \mathrm{NH}_{3}$; thiourea $(0.2 \mathrm{M})$; temperature of bath, $30^{\circ} \mathrm{C} ; \mathrm{pH}$ of the bath, $\left.9-10\right)$. 
In order to study the thickness dependent properties, films having different thicknesses were prepared by varying the deposition time from 6-20 h. Table 1 shows variation of film thickness with deposition time.

\subsection{Studies of X-ray diffractometry}

Figure 3 shows the XRD patterns of $\mathrm{ZnS}$ films deposited at $30 \pm 2{ }^{\circ} \mathrm{C}$ bath temperature for deposition periods 6,9 , 12,15 and $20 \mathrm{~h}$.

The patterns indicate that films are polycrystalline or nanocrystalline in nature. The observed broad hump in XRD patterns of all samples is due to amorphous glass substrates. Comparison of $d$-values with ASTM data for $\mathrm{ZnS}$ (ASTM Data file) shows that the material is $\mathrm{ZnS}$.

Table 1. Variation of film thickness with deposition time.

\begin{tabular}{lcc}
\hline S1. no. & $\begin{array}{c}\text { Deposition time } \\
(\mathrm{h})\end{array}$ & $\begin{array}{c}\text { Film thickness } \\
(\mathrm{nm})\end{array}$ \\
\hline (A) & 06 & 76 \\
(B) & 09 & 141 \\
(C) & 12 & 207 \\
(D) & 15 & 272 \\
(E) & 20 & 332 \\
\hline
\end{tabular}

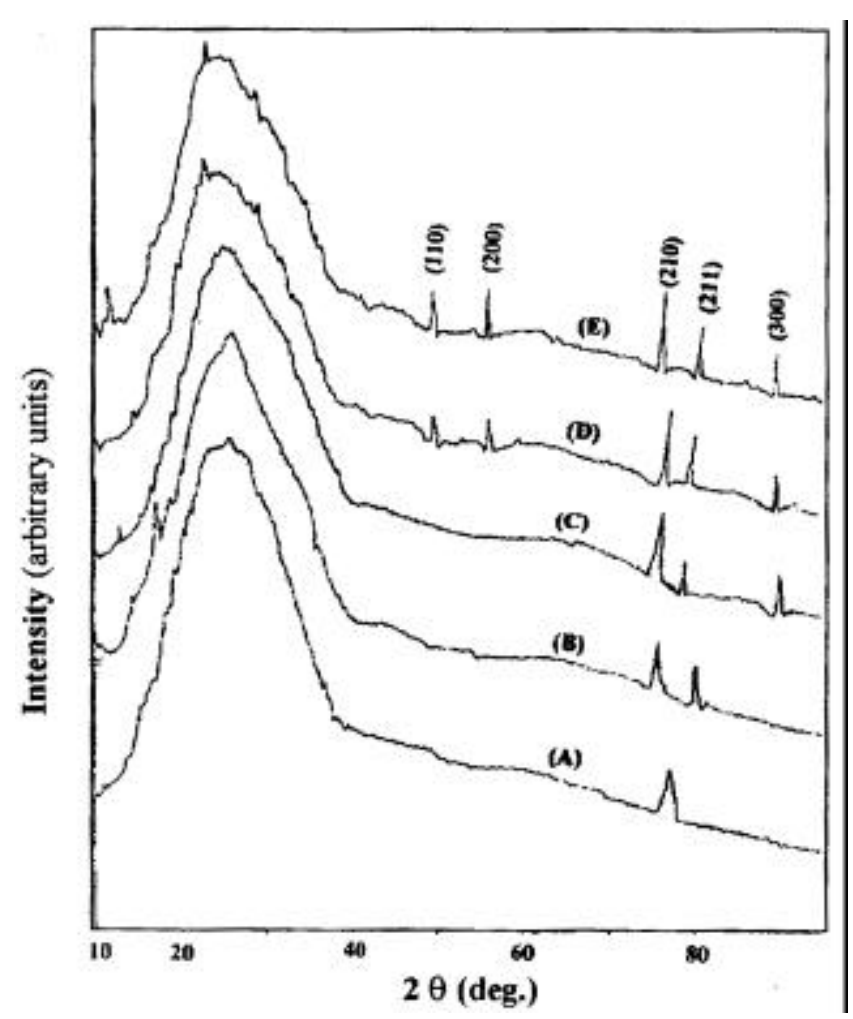

Figure 3. X-ray diffraction patterns of $\mathrm{ZnS}$ thin films for different thicknesses. (Film thickness: (A) $76 \mathrm{~nm}$; (B) $141 \mathrm{~nm}$; (C) $207 \mathrm{~nm}$; (D) $272 \mathrm{~nm}$ and (E) $332 \mathrm{~nm}$ ).
Comparison of XRD data for $\mathrm{ZnS}$ films is shown in tables 2-6.

The XRD patterns show small crystallites. The crystallinity of the films was improved with thickness. The XRD patterns matched well with the standard patterns of $\mathrm{ZnS}$, which possess hexagonal structure.

\subsection{Electrical resistivity studies}

The electrical resistivity of $\mathrm{ZnS}$ films with different thicknesses was measured using the d.c. two-point probe method in air. Figure 4 shows the variation of $\log$ of resistivity $(\log \rho)$ with reciprocal of temperature $(1 / T) \times 10^{3}$. For all films it was seen that resistivity decreases with temperature indicating semiconducting nature of films. For all the films, resistivity follows the relation

$$
\rho=\rho_{0} \exp \left(E_{0} / K T\right)
$$

Table 2. Comparison of $d$-values with ASTM data ([A] Film thickness, $76 \mathrm{~nm}$ ).

\begin{tabular}{lccc}
\hline Sl. no. & $\begin{array}{c}\text { Standard } d \text {-value } \\
(\AA)\end{array}$ & $\begin{array}{c}\text { Observed } d \text {-value } \\
(\AA)\end{array}$ & $\begin{array}{c}\text { Reflection plane } \\
(h k l)\end{array}$ \\
\hline 01 & 1.251 & 1.2504 & $(210)$ \\
\hline
\end{tabular}

Table 3. Comparison of $d$-values with ASTM data ([B] Film thickness, $141 \mathrm{~nm}$ ).

\begin{tabular}{lccc}
$\begin{array}{l}\text { S1. } \\
\text { no. }\end{array}$ & $\begin{array}{c}\text { Standard } d \text {-value } \\
(\AA)\end{array}$ & $\begin{array}{c}\text { Observed } d \text {-value } \\
(\AA)\end{array}$ & $\begin{array}{c}\text { Reflection plane } \\
(h k l)\end{array}$ \\
\hline 01 & 1.251 & 1.2584 & $(210)$ \\
02 & 1.226 & 1.2252 & $(211)$ \\
\hline
\end{tabular}

Table 4. Comparison of $d$-values with ASTM data ([C] Film thickness, $207 \mathrm{~nm}$ ).

\begin{tabular}{lccc}
\hline $\begin{array}{l}\text { S1. } \\
\text { no }\end{array}$ & $\begin{array}{c}\text { Standard } d \text {-value } \\
(\AA)\end{array}$ & $\begin{array}{c}\text { Observed } d \text {-value } \\
(\AA)\end{array}$ & $\begin{array}{c}\text { Reflection plane } \\
(h k l)\end{array}$ \\
\hline 01 & 1.251 & 1.259 & $(210)$ \\
02 & 1.226 & 1.2343 & $(211)$ \\
03 & 1.1023 & 1.1017 & $(300)$ \\
\hline
\end{tabular}

Table 5. Comparison of $d$-values with ASTM data ([D] Film thickness, $272 \mathrm{~nm}$ ).

\begin{tabular}{lccc}
$\begin{array}{l}\text { S1. } \\
\text { no. }\end{array}$ & $\begin{array}{c}\text { Standard } d \text {-value } \\
(\AA)\end{array}$ & $\begin{array}{c}\text { Observed } d \text {-value } \\
(\AA)\end{array}$ & $\begin{array}{c}\text { Reflection plane } \\
(h k l)\end{array}$ \\
\hline 01 & 1.911 & 1.8333 & $(110)$ \\
02 & 1.654 & 1.6502 & $(200)$ \\
03 & 1.251 & 1.2488 & $(210)$ \\
04 & 1.226 & 1.231 & $(211)$ \\
05 & 1.1023 & 1.1096 & $(300)$ \\
\hline
\end{tabular}


where $\rho$ is resistivity at temperature, $T, \rho_{0}$ is a constant, $K$ the Boltzmann constant $\left(1.38 \times 10^{-23} \mathrm{~J} / \mathrm{K}\right)$ and $E_{0}$ the activation energy required for conduction.

Table 6. Comparison of $d$-values with ASTM data ([E] Film thickness, $332 \mathrm{~nm}$ ).

\begin{tabular}{lccc}
\hline $\begin{array}{l}\text { Sl. } \\
\text { no. }\end{array}$ & $\begin{array}{c}\text { Standard } d \text {-value } \\
(\AA)\end{array}$ & $\begin{array}{c}\text { Observed } d \text {-value } \\
(\AA)\end{array}$ & $\begin{array}{c}\text { Reflection plane } \\
(h k l)\end{array}$ \\
\hline 01 & 1.911 & 1.9662 & $(110)$ \\
02 & 1.654 & 1.6323 & $(200)$ \\
03 & 1.251 & 1.2421 & $(210)$ \\
04 & 1.226 & 1.2290 & $(211)$ \\
05 & 1.1023 & 1.1066 & $(300)$ \\
\hline
\end{tabular}

Table 7. Variation of activation energy with film thickness.

\begin{tabular}{lcc}
\hline $\begin{array}{l}\text { Sl. } \\
\text { no. }\end{array}$ & $\begin{array}{c}\text { Film thickness } \\
(\mathrm{nm})\end{array}$ & $\begin{array}{c}\text { Activation energy } \\
(\mathrm{eV})\end{array}$ \\
\hline (A) & 76 & $1 \cdot 29$ \\
(B) & 141 & $1 \cdot 07$ \\
(C) & 207 & $0 \cdot 94$ \\
(D) & 272 & $0 \cdot 91$ \\
(E) & 332 & $0 \cdot 81$ \\
\hline
\end{tabular}

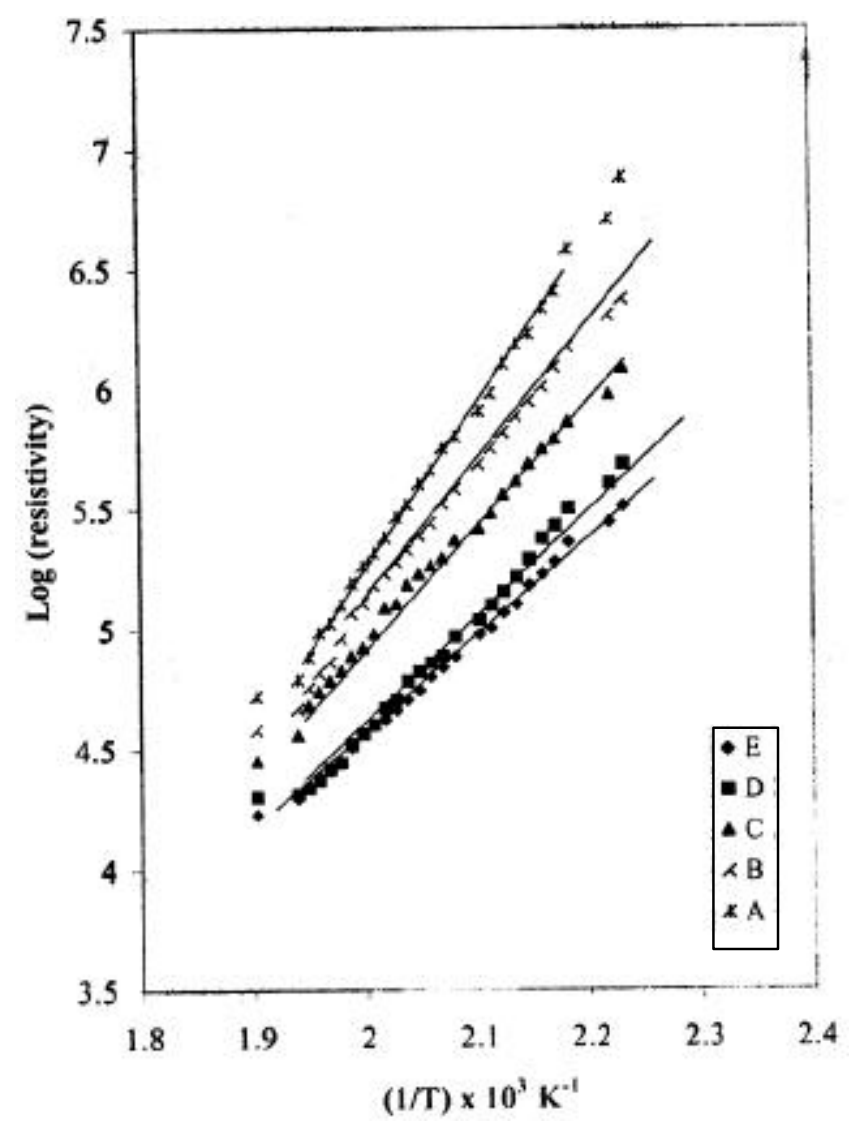

Figure 4. Variation of $\log (\rho)$ vs $1 / T \times 10^{3}\left(\mathrm{~K}^{-1}\right)$ for different thicknesses of $\mathrm{ZnS}$ films (Film thickness: (A) $76 \mathrm{~nm}$, (B) $141 \mathrm{~nm}$, (C) $207 \mathrm{~nm}$, (D) $272 \mathrm{~nm}$ and (E) $332 \mathrm{~nm}$ ).
Figure 5 shows variation of electrical resistivity, $\rho(\Omega$ $\mathrm{cm})$, with film thickness. Resistivity of $\mathrm{ZnS}$ film decreases from $1.832 \times 10^{5}(\Omega-\mathrm{cm})$ to $0.363 \times 10^{5}(\Omega-\mathrm{cm})$ as film thickness decreases from 76 to $332 \mathrm{~nm}$ at temperature, $505.5 \mathrm{~K}$. This decrease in resistivity is due to the improvement in crystallinity of the films as the film thickness was increased from 76 to $332 \mathrm{~nm}$. This observation is attributed to the size effect observed in semiconductor thin films. A similar behaviour of nanocrystalline materials prepared by different methods was reported by several workers (Liu et al 1993, 1994; Wang et al 1993; Kale et al 1996).

From the resistivity plots, the thermal activation energies were calculated using (7). Table 7 shows activation energies at different thicknesses of $\mathrm{ZnS}$ film. Activation energies are of the order of $0 \cdot 81-1.29 \mathrm{eV}$ as film thickness was decreased from 332 to $72 \mathrm{~nm}$.

\section{Conclusions}

The $\mathrm{ZnS}$ thin films have been chemically deposited from an aqueous alkaline bath and thickness of film was varied from $76 \mathrm{~nm}$ to $332 \mathrm{~nm}$, by changing deposition time. The structural and electrical properties of $\mathrm{ZnS}$ are found to be thickness dependent. The resistivity measurement shows that films are semiconducting in nature.

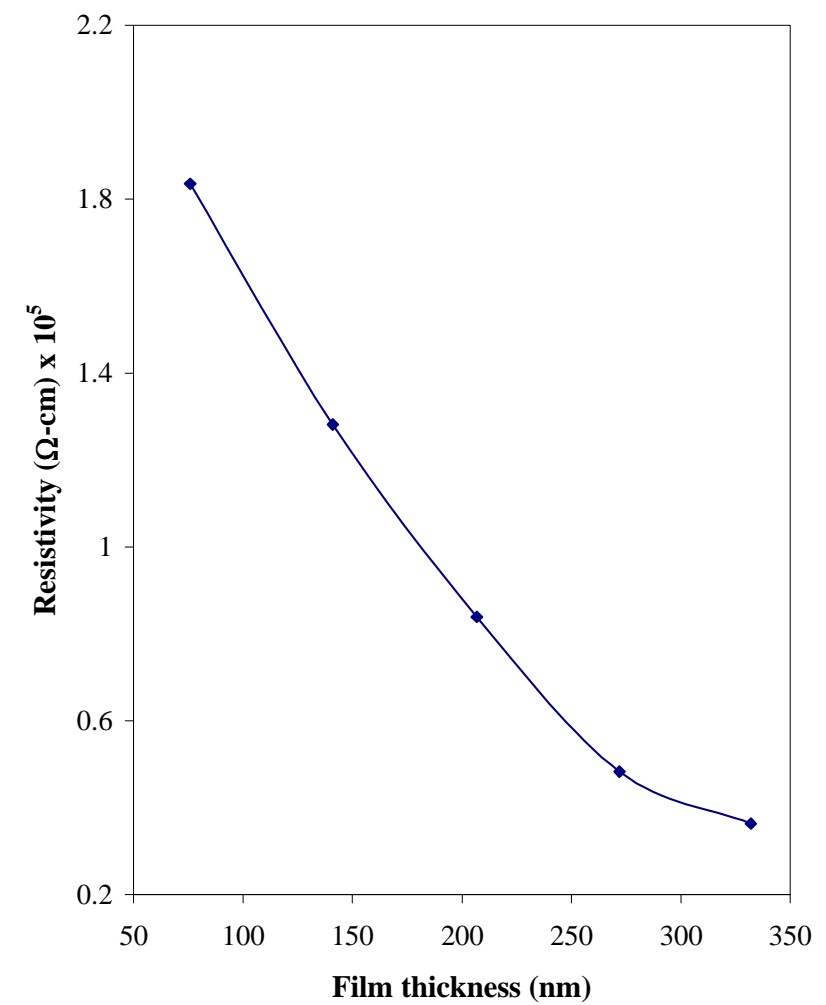

Figure 5. Plot of variation of electrical resistivity $(\rho)(\Omega$ $\mathrm{cm}) \times 10^{5}$ with $\mathrm{ZnS}$ film thickness at $500 \cdot 5 \mathrm{~K}$ temperature. 


\section{Acknowledgement}

The authors are thankful to the University Grants Commission, WRO, Pune, for financial support under the project (No. F47-15/2003).

\section{References}

ASTM diffraction data file card. No. 12-688, 10-434, 5-0492 Biswas S, Pramanik P and Basu P K 1986 Mater. Letts 481 Dona J M and Herrero J 1992 This Journal 1392810

Kale S S, Jahav U S and Lokhande C D 1996 Indian J. Pure \& Appl. Phys. 34324

Kaur I, Pandya D K and Chopra K L 1980 This Journal 127 943
Kitaev G A and Sokolova T P 1970 Russ. J. Inorg. Chem. 15167 Kitaev G A, Uritskaya A A and Mokrushin S G 1965 Russ. J. Inorg. Chem. 391101

Liu X D, Wang J T and Ding B Z 1993 Metall. Mater. Sci. 28 59

Liu X D, Wang J T and Zhu J 1994 J. Mater. Sci. 29929

Lokhande C D 1991 Mater. Chem. Phys. 28145

Mach R and Muller G O 1982 Phys. Status Solidi A69 11

Orient Tom 1994 J. Electrochem. Soc. 1411320

Ortega Borges R, Lincot D and Vedel J 1992 Paper presented at 11th European photovoltaic solar energy conference, Montreaux

Padam G K, Malhotra G L and Rao S U M 1988 J. Appl. Phys. 63770

Wang Y Z, Qioa G W, Liu X D, Ding B Z and Hu Z Q 1993 Mater. Lett. 17152 